\title{
POTENTIAL OF LACTIC ACID BACTERIA FROM TAPE AND JEMBER TEMPEH AS A PROBIOTIC CANDIDATE
}

\author{
Siti Nur Azizah"1, Mikhania Christiningtyas Eryani², Azizah ${ }^{3}$
}

Received : July 30, 2021

Accepted : October 29, 2021

DOI: 10.15575/biodjati.v6i2.9462

1,2Akademi Farmasi Jember,

Pangandaran street No. 42 Antirogo, Jember 68125, East Java, Indonesia. Tel./Fax: (0331) 338884

${ }^{3}$ Department of Biology, Faculty of Mathematics and Natural Sciences, Universitas Jember, Kalimatan street No. 37 Kampus Tegalboto, Jember 68121, East Java, Indonesia. Telp: (0331) 334293, Fax: (0331) 330225

e-mail:

*1azizah.ariza@gmail.com

${ }^{2}$ mikhaniachristi@gmail.com

3azizah.bafared@gmail.com

*Corresponding author

Abstract Probiotics are microbes in fermented foods that have beneficial effects on health. Microbes that act as probiotics are lactic acid bacteria (LAB) that can produce metabolites such as lactic acid, hydrogen peroxide, and bacteriocins. This study aimed to obtain lactic acid bacterial isolates from tape and tempeh, and to test the potential of $L A B$ as a probiotic candidate by activity test as an antidiarrhea and its resistance to gastric $p H$ and bile salts. The fermentation products used as a source of LAB isolates are tempeh sumber mas merk, and yellow cassava tape, sari madu merk from Jember. The results of the first stage regarding the isolation of $L A B$ using GYP media showed that there were 2 LAB isolates (TaJ.14 and TaJ.15) from the tape and 4 LAB isolates (TeJ.18, TeJ.22, TeJ.24, and TeJ.25) from tempeh. The results of the antidiarrheal test using the disc diffusion method (oxoid) showed that TaJ.14 and TaJ.15 isolates were able to inhibit Bacillus subtilis, Escherichia coli, and Shigella dysentriae, while TeJ.18, TeJ.22, TeJ.24, TeJ.25, and Lactobacillus casei (control) was only able to inhibit B. subtilis and E. coli. The results of $L A B$ resistance to gastric $p H$ showed that the TeJ.25 isolate had the highest percentage of $\mathrm{pH} 3$ and 2.5 resistance (51.13 and $33.03 \%)$ compared to other isolates and controls. LAB resistance test results against bile salts (oxgal) showed that the TeJ.22 isolate had the highest percentage of resistance $(75.10 \%)$ compared to other isolates although was still higher in control (75.99\%).

Keywords: antidiarrheal, Lactic acid bacteria, probiotic, tape, tempeh

\section{Citation}

Azizah, S. N., Eryani, M. C. \& Azizah. (2021). Potential of Lactic Acid Bacteria From Tape and Jember Tempeh as a Probiotic Candidate. Jurnal Biodjati, 6(2), 273-283.

\section{INTRODUCTION}

Public awareness is increasing about the importance of health so that they can change their lifestyle to consume functional food, namely food that contains a certain component and has a positive effect on body health. One of the main components in a food product is the presence of lactic acid bacteria (LAB) that has a great contribution in providing functional benefits to the human body as a probiotic.

Probiotics are living microbes in food that have beneficial effects on the health and life of their hosts (Tamime et al., 2005). Probiotics produce metabolites that include lactic acid, hydrogen peroxide, and bacteriocin that can inhibit growth and kill pathogenic bacteria so that they have therapeutic benefits. Probiotics help treat lactose intolerance, prevent colon cancer, and lower blood cholesterol levels (Pato et al., 2014). Probiotics are widely used as food supplements to treat antidiarrhea and increased immunomodulators (Rahmah et al., 2017; Situmeng et al., 2017; Rusli et al., 2018). 


\section{JURNAL BIDDJATI}

http://journal.uinsgd.ac.id/index.php/biodjati

Medicinal or food preparations containing probiotics have been circulating in the market and used by the public for various purposes (Allen et al., 2011) and to increase the body's immune system. Probiotics used either as drugs such as Lacto-B or food supplements can exist in the form of bacterial biomass trapped in a certain matrix or liquid dosage forms such as yogurt. Besides, probiotics are found in various fermented products of Indonesia, such as tempeh and tape. These products have been circulating in many traditional markets, supermarkets, and souvenir centers in Jember. This fermented product has a distinctive taste and is even in demand by people outside the city of Jember.

According to Nurdini et al. (2015), every unique taste in each fermented product is not only caused by the raw material and yeast but also due to the presence of natural microbes in the production environment. These microbes do not intentionally contribute during the fermentation process because, during production, the tools and environment used are not sterilized. So, these natural microbes will come to live on raw materials and give additional benefits for human health.

Fermentation products such as tempeh and tape are deliberate fermentation because they require an additional starter in the form of yeast/fungi to break down complex compounds into simple compounds. Tempe fermentation involves a complex microbial community, which develops from the beginning of the immersion process and reaches the maximum amount in fresh tempeh. LAB is the dominant microbe in tempeh with the amount $\left(10^{7}-10^{8}\right.$ CFU/g) (Efriwati et al., 2013; Nurdini et al., 2015). Meanwhile, the tape is a traditional fermented food made from cassava and sticky rice. Based on Gultom's research (2016) LAB is present in quite high amounts in sticky rice and cassava tape $\left(10^{7}-10^{8} \mathrm{CFU} / \mathrm{g}\right)$.
Based on the statement, this study aimed to isolate $\mathrm{LAB}$ from Jember fermentation products, namely tape and tempeh. Theproducts used were certain brands that has a more distinctive taste and is most in demand by the public. The LAB isolates obtained will then be tested for their ability as probiotics which include antidiarrhea lactivity tests, their resistance test at low $\mathrm{pH}$, and salt. The results of this study are expected to produce LAB isolates that have higher diversity and ability than other studies. This is because microbes isolated from different environments also cause metabolic differences that will affect the ability of the metabolites produced by these microbes.

\section{MATERIALS AND METHODS}

This research was conducted from December 2019 to July 2020 at the Microbiology collections from the Microbiology Laboratory, University of Jember and Shigella dysenteriae as collection from Microbiology Laboratory, University of Indonesia.

The fermented products used are Tempeh (Sumber Mas) and yellow cassava tape (Sari Madu). Each product was taken at 72 hours of fermentation from one of the souvenir shops in Jember, with the samples condition were ripe and ready to eaten. According to Nurdini (2015), lactic acid bacteria have entered the end logarithmic phase or optimum growth at 72 hours of fermentation. Pathogenic bacteria used for antidiarrhea testing include Escherichia coli and Bacillus subtilis as collections from the Microbiology Laboratory, University of Jember and Shigella dysenteriae as collection from Microbiology Laboratory, University of Indonesia. 


\section{JURNAL BIDDJATI}

http://journal.uinsgd.ac.id/index.php/biodjati

\section{Isolation of Lactic Acid Bacteria (LAB)}

A total of 50 grams of sample was added aseptically to $450 \mathrm{~mL}$ of $\mathrm{NaCl}(0.85 \%$, w/v) and homogenized. Then, a gradual dilution from a $10^{-1}$ to $10^{-7}$ dilution was carried out. The results of dilution from $10^{-3}$ to $10^{-7}$ were taken $100 \mu \mathrm{l}$ and then planted on Glucose Yeast Peptone (GYP) media using the spread plate method. The dilution level was chosen because before the $10^{-3}$ dilution the growth of lactic acid bacteria colonies was still crowded. Subsequently, incubated for 48 hours in an incubator at $37^{\circ} \mathrm{C}$ (Nurdini et al., 2015). LAB isolates grew marked with a clear zone around the colony.

LAB isolates isolated from tempeh were coded "Te" and tape was coded "Ta". Tape and tape come from Jember so they are given the code "J". The number of LAB isolates that grew with different colony characters were coded according to the number of colonies obtained. For example, TaJ.14 is the code for LAB isolates isolated from Jember Tape in the $14^{\text {th }}$ order.

\section{Purification and Characterization of LAB Isolates}

The purification of the mixed isolates was carried out by means of quadrant streaks on GYP media and incubated for 48 hours at $37{ }^{\circ} \mathrm{C}$ (Nurdini et al., 2015). The pure isolate obtained was measured for its clear zone and characterized. Macroscopic characteristics were carried out by observing the form, elevation, margin, surface and opacity of the colony, and colony size using a stereomicroscope. Microscopic observation was carried out by Gram staining by observing the form and color of the gram using a microscope (Sulmiyati et al., 2011). The pure isolate was then stored in a GYP tube inclined medium at $4{ }^{\circ} \mathrm{C}$ for further testing.

\section{Antidiarrhea Activity Testing.}

Antidiarrhea testing was carried out by the paper disc diffusion (oxoid) method. A warm NA medium containing $100 \mu \mathrm{l}$ of pathogenic bacterial suspension was poured on a sterile petri dish. Then as much as $20 \mu 1$ of LAB suspension on disc paper was affixed to the agar surface and incubated at $37^{\circ} \mathrm{C}$ for 48 hours. The presence of a clear zone around the disc paper indicates that LAB isolates can inhibit pathogenic bacteria. The diameter of this clear zone is measured with a caliper in millimeters. This antimicrobial activity test was repeated three times (Savadogo et.al., 2004).

\section{Low pH Resistance Testing}

Testing for bacterial resistance to low $\mathrm{pH}$ (2.5) was carried out following the plate count method with modification of the $\mathrm{pH}$ of the media for acidity testing. A total of $10 \mathrm{ml}$ of lactic acid bacterial culture in liquid GYP aged 24 hours harvested, then resuspended as much as $1 \%(\mathrm{v} / \mathrm{v})$ each into $9 \mathrm{ml}$ of liquid GYP (control) and liquid GYP pH 2.5 and 3.0 (plus $10 \% \mathrm{HCl}$ ), and then incubated at $37{ }^{\circ} \mathrm{C}$ for 120 minutes. Testing for bacterial resistance to low $\mathrm{pH}$ (2.5) was carried out three times. The resistance of isolates to low $\mathrm{pH}$ was measured using the spectrophotometric method by calculating the difference in the percentage growth of control and treatment (Halim \& Elok, 2013).

\section{Resistance Test to Bile Salt}

Testing for bacterial resistance to bile salts was carried out following the plate count method. A total of $10 \mathrm{ml}$ of lactic acid bacterial culture in 24 hour liquid GYP harvested, then resuspended as much as $1 \%(\mathrm{v} / \mathrm{v})$ each into $9 \mathrm{ml}$ of liquid GYP (control) and liquid GYP added with Oxgall 3\% (w/v), then incubated at $37^{\circ} \mathrm{C}$ for 120 minutes. Testing for bacterial 


\section{JURNAL BIODJATI}

http://journal.uinsgd.ac.id/index.php/biodjati

resistance to bile salts was carried out three times. The resistance of isolates to bile salts was measured using the spectrophotometric method by calculating the difference in the percentage growth of control and treatment (Halim \& Elok, 2013).

\section{RESULTS AND DISCUSSION}

\section{The Isolation of Lactic Acid Bacteria from Tape and Tempe Jember}

A total of 6 isolates of lactic acid bacteria (LAB) have been isolated from fermentation products, namely tape and tempeh from Jember. All of these isolates were $\mathrm{LAB}$ which was able to grow on GYP media. In general, LAB activity is indicated by the ability to grow on GYP plate media containing $\mathrm{CaCO} 3$ (Figure 1). According to Yulinery \& Nurhidayat (2013), the clear zone shows the work of alkaline $\mathrm{CaCO} 3$ (Calcium carbonate) in GYP media which can neutralize the production of acid excreted by LAB isolates (Figure 1). Therefore, the addition of $\mathrm{CaCO} 3$ to the growing medium is intended as an early-stage selection in the isolation and purification of LAB.

The isolation results showed that there were $2 \mathrm{LAB}$ isolates from tape and 4 $\mathrm{LAB}$ isolates from tempeh that had different activities in forming clear zones around their colonies (Table 1). According to Situmeng et al., (2017), apart from lactic acid that is secreted by GYP media, LAB also produces other important metabolites such as hydrogen peroxide and bacteriocin. The content of these metabolites causes probiotics to have therapeutic benefits that are useful in treating lactose intolerance, preventing colon cancer, reducing cholesterol levels in the blood, overcoming diarrhea, and increasing immunomodulators.

Table 1 showed that TeJ.24, TeJ.24, and TeJ.25 isolates had the highest clear zone diameters of $18.00 \%, 17.83 \%$, and $11.73 \%$ respectively compared to other $\mathrm{LAB}$ isolates and controls. The larger the diameter of the clear zone produced, the greater the activity in producing lactic acid secreted by LAB into GYP media.
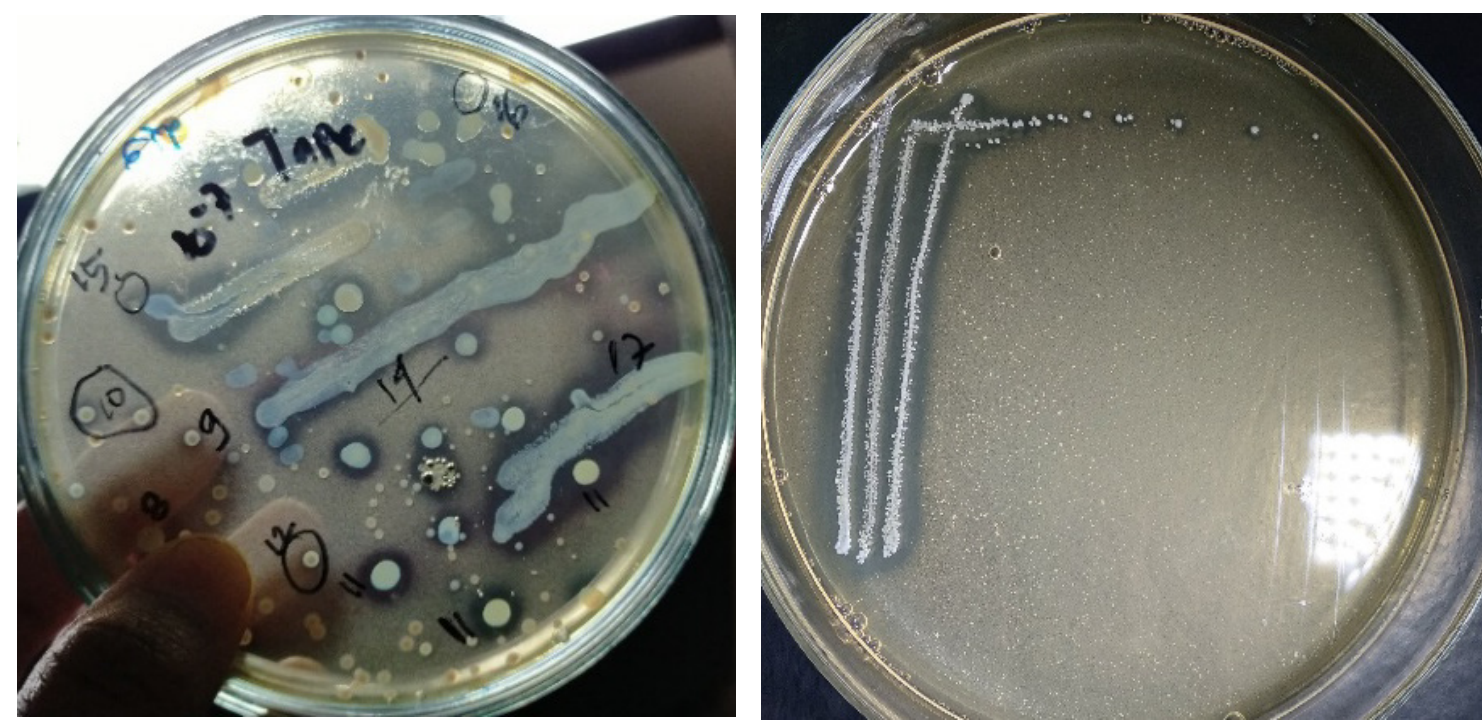

Figure 1. Mixed isolates and purification of lactic acid bacteria (LAB) from tempeh and tape using GYP media incubation for 24 hours. A) mixed isolate, b) purification of LAB isolates 


\section{JURNAL BIODJATI}

http://journal.uinsgd.ac.id/index.php/biodjati

Table 1. The diameter of the clear zone of LAB from tape and tempeh on GYP media was incubated for 48 hours

\begin{tabular}{ll}
\hline Isolate Code & \multicolumn{1}{c}{ Clear Zone $(\mathbf{m m})$} \\
\hline TaJ.14 & $11.00 \pm 0.57$ \\
\hline TaJ.15 & $5.66 \pm 0.36$ \\
\hline TeJ.18 & $8.33 \pm 0.55$ \\
\hline TeJ.22 & $18.00 \pm 0.28$ \\
\hline TeJ.24 & $17.83 \pm 0.47$ \\
\hline TeJ.25 & $11.73 \pm 0.50$ \\
\hline L. casei & $11.50 \pm 0.50$
\end{tabular}

Morphological Characteristics of LAB Isolates from Tape and Tempe Jember

Based on table 2, as many as 6 LAB isolates have the same colony and cell morphology. The colony is circular, convex elevation, margin entire, smooth surface, opacity opaque, the same milky white color as Lactobacillus casei. The results of Gram staining showed that the six LAB isolates had the form of bacillus cells and were Grampositive. The six LAB isolates in this study were thought to be Lactobacillus. According to Anguirre \& Colins (1993) that lactic acid bacteria consists of the genera Lactobacillus, Streptococcus, Leuconostoc, and Pediococcus. Lactobacillus are lactic acid bacteria that have the form of bacillus cells. Meanwhile, genera other than Lactobacillus have coccus cells.

According to Bansal et al. (2013),

Table 2. Characteristics of LAB isolates from tape and tempeh Jember

\begin{tabular}{lllllllc}
\hline \multirow{2}{*}{ Isolate Code } & \multicolumn{2}{c}{ Colony Morphology } & \multicolumn{2}{c}{ Cell } \\
\cline { 2 - 7 } & Circular & Convex & Entire & Smooth & Opaque & Bacil & Positive \\
\hline TaJ.14 & Circular & Convex & Entire & Smooth & Opaque & Bacil & Positive \\
\hline TaJ.15 & Circular & Convex & Entire & Smooth & Opaque & Bacil & Positive \\
\hline TeJ.18 & Circular & Convex & Entire & Smooth & Opaque & Bacil & Positive \\
\hline TeJ.22 & Circular & Convex & Entire & Smooth & Opaque & Bacil & Positive \\
\hline TeJ.24 & Circular & Convex & Entire & Smooth & Opaque & Bacil & Positive \\
\hline TeJ.25 & Circular & Convex & Entire & Smooth & Opaque & Bacil & Positive \\
\hline L. casei & & & &
\end{tabular}

Antidiarrhea Activity Test of LAB Isolates from Tempeh and Tape

Antibacterial is an antagonistic ability of a chemical compound to inhibit the growth of unwanted microbes. This study used E. coli Jurnal Biodjati 6(2):273-283, November 2021
Generally, Lactobacillus and Bifidobacterium are the main strains used as probiotics. Other genera such as Lactococcus, Enterococcus, Streptococcus, Saccharomyces, and Propionibacterium have also been used as probiotics. Touw (2014)has identified LAB isolates from tempeh, namely Enterococcus faecium, L. plantarum, P. acidilactici, Wisella confusa, P. pentosaceus, and L. fermentum. Meanwhile, according to Panjaitan et al. (2018) LAB grows on tape include P.acidilactici NG6-4, L.fermentum BK25, and L. Fermentum BK2-7. Ratihwulan (2016) reported LAB found in sticky rice and cassava tape consists of three types, namely Homofermentative cocci, Homofermentative bacillus, and Heterofermentative bacillus. 


\section{JURNAL BIDDJATI}

http://journal.uinsgd.ac.id/index.php/biodjati

While isolates TaJ.18, TaJ.22, TaJ.24, TaJ.25 were only able to inhibit $B$. Subtilis and E. coli in moderate to strong categories.

The six LABs have a broad spectrum by inhibiting Gram-positive and Gramnegative bacteria (Table 3). According to Radlovic et al. (2015), diarrhea is caused by viruses $(70 \%)$, bacteria $(10-20 \%)$, and protozoa $(10 \%)$. Bacteria that cause diarrhea include Campylobacter jejuni, Salmonella (animal/non-typhoidal species), Shigella, Yersinia enterocolitica, Escherichia coli (enteropathogenic and enterotoxigenic), Yersinia pseudotuberculosis, Clostridium difficile, Salmonella typhi and paratyphi, as well as Vibrio cholerae. Other bacteria that cause infectious diseases are Bacillus subtilis, which are abundant in the intestine, which cause diarrhea transmitted through food contamination.

Figure 2 shows that commercial probiotic L. Casei isolates can inhibit E.coli and B.subtilis with the highest activity value than other isolates, but have the same inhibition category as TaJ.14, TeJ.22, TeJ.24, and TaJ.25 isolate which are strong. According to Mirnejad et al. (2013), L.casei can inhibit $S$. Sonnei and S. Flexneri stain MDR, but there have been no previous reports about its inhibition against S.dysentriae and B.subtilis. According to Pato et al. (2017), L.casei Shirota stain is also able to inhibit E.coli, S.aureus, Liesteria monocytogenes in the moderate to strong category. Lactic acid bacteria isolates from the study of Savadogo et al. (2004) were also able to inhibit E.coli and B.careus in the strong category on MRS agar medium. So that TaJ.14 and TaJ.15 isolates in this study were the first reports of LAB isolates that able to inhibit $S$. dysentriae and B.subtilis.

The results of antidiarrhea activity testing of LAB isolates against pathogenic bacteria were shown by the formation of a clear zone/inhibition zone around the disc (Figure 3). The zone of inhibition was formed because of the antibacterial mechanism of LAB isolates from tape and tempeh by secreting organic acids on GYP media. The state of decreasing $\mathrm{pH}$ is accompanied by the undissociated form of the molecule. At $\mathrm{pH}$ below 5, the undissociated organic acid molecules are very high, causing organic acids to tend to be lipophilic and enter through the cell membrane. The $\mathrm{pH}$ in the cell becomes lower which causes the dissociation of acid molecules so that protons $(\mathrm{H}+)$ and anions are released. The amount of acid that is not dissociated can change the permeability of the cell membrane and cause the destruction of the material transport system in the pathogenic bacteria. This results in cell death. Organic acids especially lactic acid are bactericidal at $\mathrm{pH} 4.5$ with concentrations above $0.2 \%$ (Ray \& Daeschel, 1992).

This antidiarrhea testing is important because acute diarrhea is still a common problem found worldwide. Meanwhile, in several hospitals in Indonesia, the data show acute diarrhea due to infection showed that there are one to four adult patients who come for treatment at the hospital because of diarrhea. $E$. coli is a major cause of diarrhea in travelers through food contamination with mucosal invasion and enterotoxins. Most patients with ETEC, EPEC, or EAEC have mild symptoms consisting of watery diarrhea, nausea, and abdominal cramps. Shigella causes bacillary dysentery and produces an inflammatory response in the colon via invasion and enterotoxins. Shigellosis presents with symptoms of abdominal pain, fever, bloody stools, and mucus stools. While B.subtilis is a secondary infection that occurs during diarrhea. Therefore, the potential for $\mathrm{LAB}$ isolates from tape and tempeh can be used as a reference in the development of probiotics. 
Jurnal Biodjati 6(2):273-283, November 2021

\section{JURNAL BIODJATI}

http://journal.uinsgd.ac.id/index.php/biodjati

Table 3. Antibacterial activity of LAB isolates from tape and tempeh Jember against pathogenic bacteria cause diarrhea.

\begin{tabular}{|c|c|c|c|c|c|c|}
\hline \multirow[b]{2}{*}{ Isolates Code } & \multicolumn{3}{|c|}{ Inhibition zone (mm) } & \multicolumn{3}{|c|}{ Note ${ }^{n}$} \\
\hline & $\begin{array}{c}\text { Bacillus } \\
\text { subtilis }\end{array}$ & $\begin{array}{c}\text { Escherichia } \\
\text { coli }\end{array}$ & $\begin{array}{c}\text { Shigella } \\
\text { dysentriae }\end{array}$ & $\begin{array}{l}\text { Bacillus } \\
\text { subtilis }\end{array}$ & $\begin{array}{c}\text { Escherichia } \\
\text { coli }\end{array}$ & $\begin{array}{c}\text { Shigella } \\
\text { dysentriae }\end{array}$ \\
\hline TaJ.14 & $9.42 \pm 0.62$ & $8.00 \pm 1.97$ & $4.83 \pm 2.59$ & Strong & Strong & Moderate \\
\hline TaJ.15 & $4.67 \pm 2.02$ & $3.97 \pm 2.00$ & $6.17 \pm 0.28$ & Moderate & Moderate & Strong \\
\hline TeJ.18 & $4.00 \pm 0.00$ & $4.67 \pm 0.00$ & - & Moderate & Moderate & Not inhibit \\
\hline TeJ.22 & $9.67 \pm 1.30$ & $8.00 \pm 2.56$ & - & Strong & Strong & Not inhibit \\
\hline TeJ.24 & $8.63 \pm 1.30$ & $7.67 \pm 2.80$ & - & Strong & Strong & Not inhibit \\
\hline TeJ.25 & $8.27 \pm 1.93$ & $8.00 \pm 3.24$ & - & Strong & Strong & Not inhibit \\
\hline L. casei & $20.40 \pm 2.70$ & $8.42 \pm 3.97$ & - & Strong & Strong & Not inhibit \\
\hline
\end{tabular}

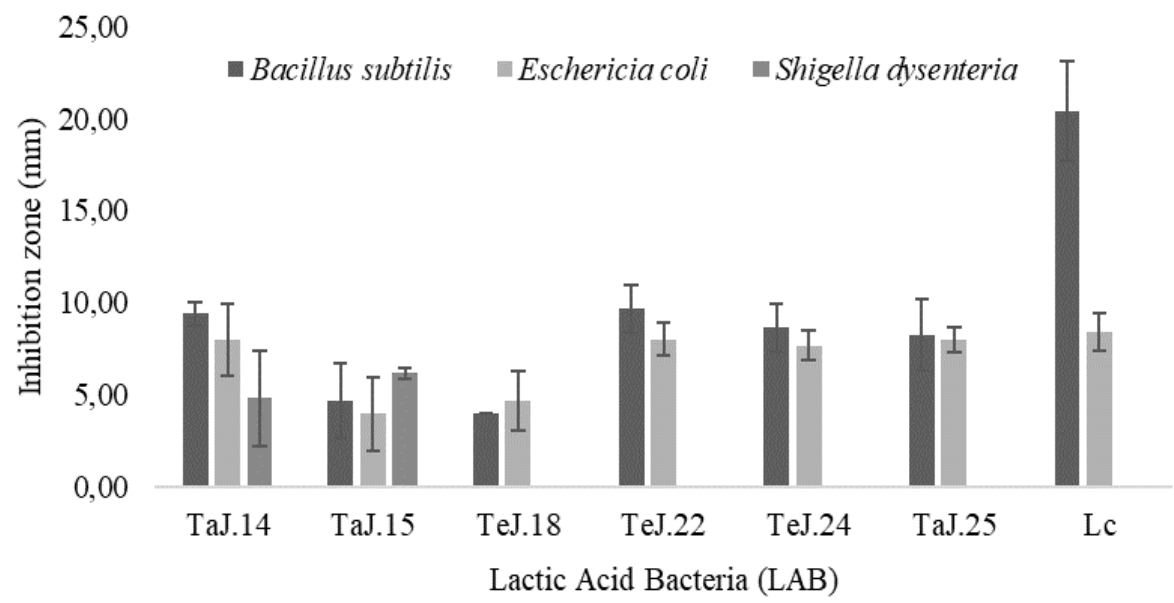

Figure 2. The results of the antidiarrhea activity test of LAB isolates against pathogenic bacteria cause diarrhea

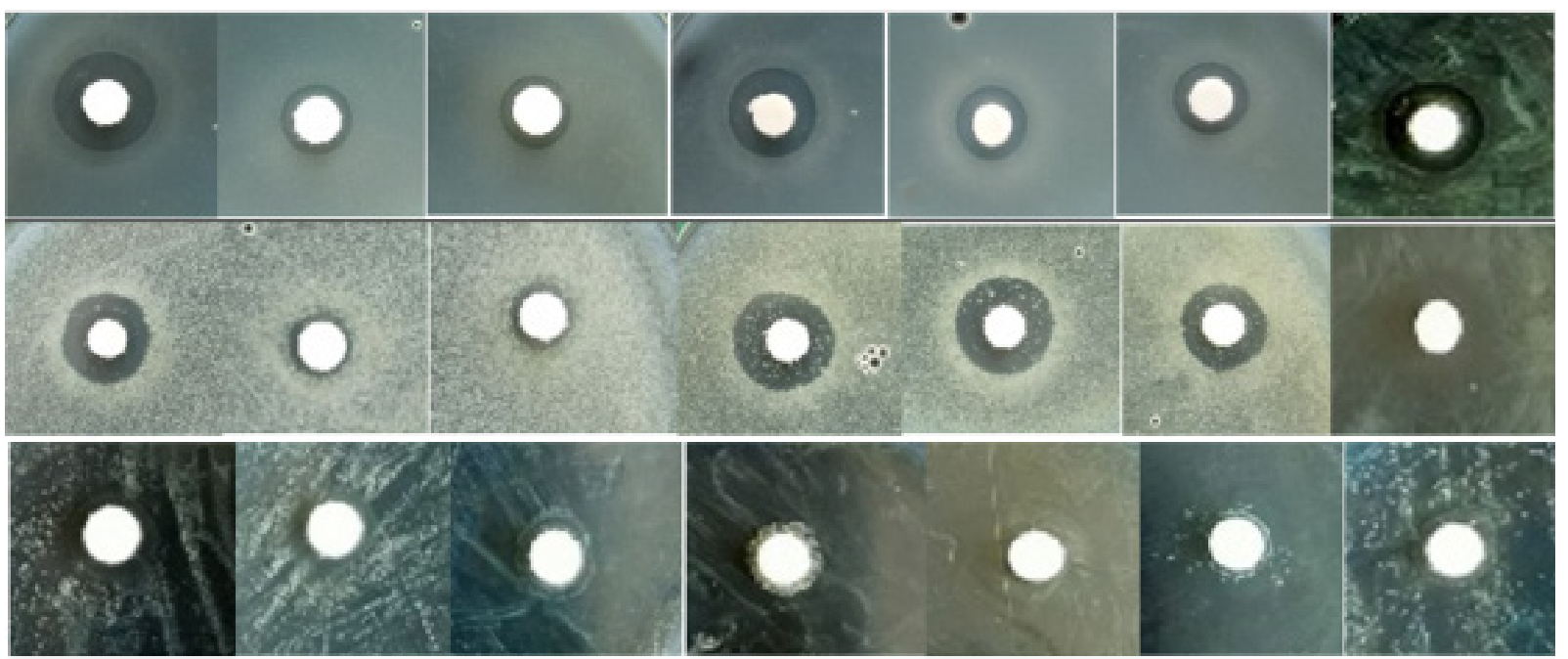

Figure 3. The activity test of LAB isolates as antidiarrhea 11 indicated by the zone of inhibition around the disc paper gainst B. subtilis (top), E. coli (middle), and S.dysenteria (bottom) on 24-hour incubation GYP media. From left to right, the isolates were TaJ.14, TaJ.15, TeJ.18, TeJ.22, TeJ.24, TeJ.25, and L.casei. 


\section{JURNAL BIDDJATI}

http://journal.uinsgd.ac.id/index.php/biodjati

\section{The Resistance Test of LAB Isolates Against Low pH}

Generally, isolate resistance at $\mathrm{pH} 2.5$ tends to be lower than $\mathrm{pH}$ 3.0. Isolate TeJ.25 has a low $\mathrm{pH}$ resistance of $33,05 \%$ at $\mathrm{pH}$ 2.5 and $51,13 \%$ at $\mathrm{pH} 3.0$, which is higher than $\mathrm{LAB}$ isolates from tape, tempeh and commercial probiotic L. casei isolates (Figure 4). LAB isolates from tape and tempeh can withstand $\mathrm{pH} 2.5$ and 3.0 conditions which can be caused by the ability of these isolates to maintain $\mathrm{pH}$ in their cells that are more neutral than their environment. Besides, it can also be caused by the bacterial cell membrane being more resistant to exposure to acids in the environment. The difference in resistance of bacterial cell membranes to damage due to a decrease in extracellular $\mathrm{pH}$ causes a diversity of cell resistance at low $\mathrm{pH}$.
Lactic acid bacteria are also able to maintain a more alkaline cytoplasmic $\mathrm{pH}$ than extracellular $\mathrm{pH}$, but a decrease in intracellular $\mathrm{pH}$ continues along with a decrease in extracellular $\mathrm{pH}$ which supports their tolerance to acids. The diversity of fatty acid and protein composition of bacterial species is also thought to affect the diversity of bacterial resistance to low $\mathrm{pH}$ (Siegumfeldt et al., 2000). There are also enzymes bound to the cell membrane that can carry out reversible reactions acting as pumps that move ions. These enzymes catalyze the movement of protons across the cell membrane as a result of hydrolysis or ATP synthesis. The resistance of isolates to low extracellular $\mathrm{pH}$ depends on the internal $\mathrm{pH}$ regulation of the bacteria (Nannen \& Hutkins, 1991).

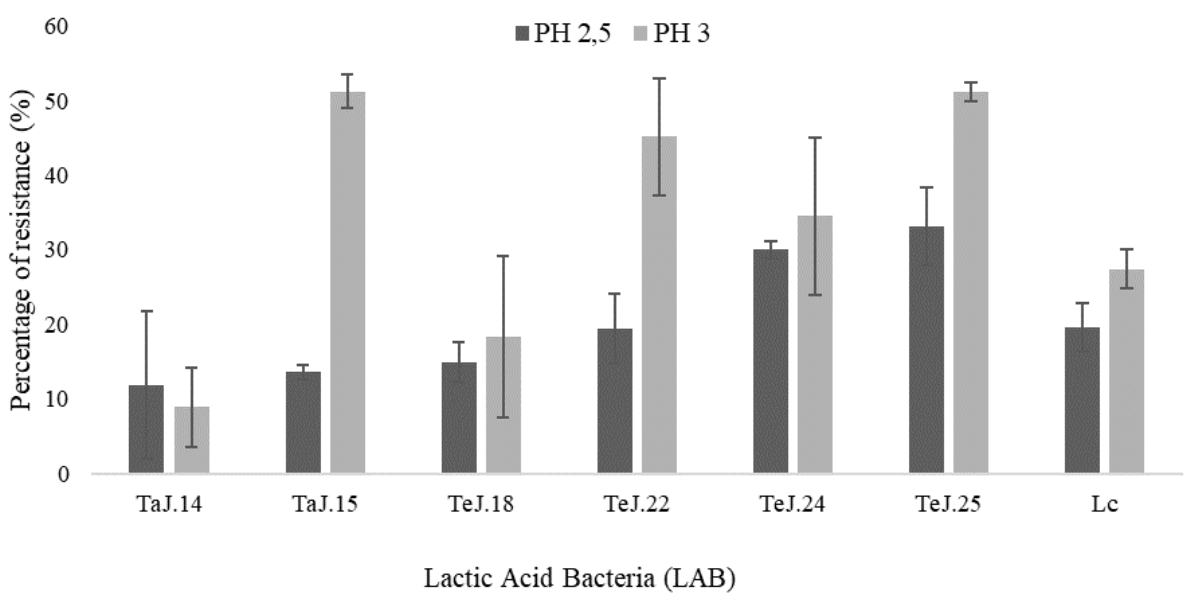

Figure 4. The results of the resistance test of $\mathrm{LAB}$ isolates from tape and tempe Jember against low $\mathrm{pH}$

\section{The Resistance Test of LAB Isolates Against Bile Salt}

All tested isolates had resistance to growth in media containing $3 \%$ ox gall salt after incubation for 24 hours at $37^{\circ} \mathrm{C}$. The TeJ.22 isolate had a higher percent resistance than the L. casei control isolate was $75.1 \%$ (Figure 5). The degree of resistance to bile Azizah et al. salts is an important characteristic of lactic acid bacteria, because it affects their activity in the digestive tract, especially the upper intestinal tract where bile is secreted. Bile is a surface-active compound.

This property also causes the active lipolytic enzymes secreted by the pancreas. This enzyme reacts with fatty acids in the 


\section{JURNAL BIDDJATI}

http://journal.uinsgd.ac.id/index.php/biodjati

cytoplasmic membrane of bacteria, resulting in changes in membrane structure and permeability properties. The diversity of the structure of fatty acids in the cytoplasmic membrane of bacteria causes differences in their permeability and characteristics that may affect their resistance to bile salts (Susanti et.al., 2007).

The ability to survive in the concentration of bile salts is also related to the ability of the isolates to produce Bile Salt Hydrolase (BSH). Some Lactobacillus have the enzyme Bile Salt Hydrolase (BSH) with the activity to hydrolyze bile salts that can change the physicochemical properties of bile salts to be non-toxic to lactic acid bacteria (Evanikastri, 2003). Several factors determine the reaction of bile to cell membranes, including the concentration of bile, the type and structure of bile, as well as membrane architecture, and cell composition play an important role in bile resistance (Begley et al., 2004).

Based on the results of this study, our research results are considered to be important in developing our knowledge of probiotics. Lactic acid bacteria in TaJ.14, TeJ.22, and TeJ.25 isolates from this study can be developed as probiotic candidates. These probiotic candidates will be formulated into food supplements to treat antidiarrhea. Suggestions for further research are to optimize growth in potential LAB isolates such as isolates TaJ.14, TeJ.22, and TeJ.25

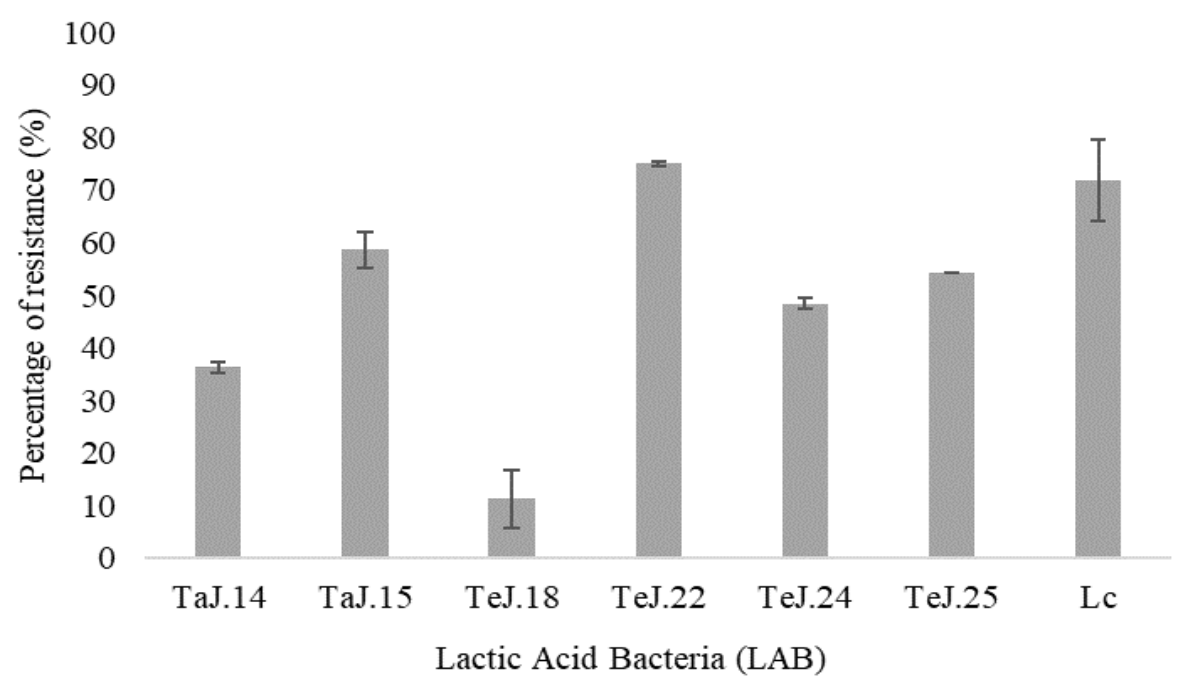

Figure 5. The results of the resistance test of LAB isolates from tape and tempe Jember against bile salt

\section{. ACKNOWLEDGMENTS}

This research was funded by Jember of Pharmacy Academy in internal research program of 2020 organized by Institute for Research and Community Service with contract No. 04/LPPM/I/2020.

\section{REFERENCES}

Allen, S.J., Martinez, E.G., Gregorio, G.V \& Dans, L.F. (2011). Probiotics for Treating Acute Infectious Diarrhea. Sao Paulo Medical Journal, 129(3):185.

Anguirre, M \& Colins, M. (1993). Lactic Acid Bacteria and Human Clinical Infection. 


\section{JURNAL BIDDJATI}

http://journal.uinsgd.ac.id/index.php/biodjati

Journal of Applied Bacteriology., 75(2):95-107.

Bansal,S., Apoorva, S., Manisha, M. \& Satish, K.S. (2013). Isolation and Characterization of Lactic Acid Bacteria from Fermented Foods. Vagetos, 26(2), 325-330.

Begley, M., Cormac, G.M.G \& Colin, H. (2004). The Interaction Between Bacteria and Bile. FEMS Microbiology. Reviews, 29, 625-651.

Efriwati, Suwanto, A., Rahayu, G. \& Nuraida L. (2013). Population Dynamics of Yeast and Lactic Acid Bacteria (LAB) During Tempeh Production. Hayati Journal Bioscience, 20(2), 57-64.

Evanikastri. (2003). Isolasi dan Karakterisasi Bakteri Asam Laktat dari Sampel Klinis yang Berpotensi sebagai Probiotik. Tesis. Institut Pertanian Bogor.

Gultom, G. M. (2016). Komposisi Mikroorganisme dan Komposisi Kimia Tape yang Diproduksi di Daerah Bogor. Skripsi. Depatemen Ilmu dan Teknologi pangan, Institut Pertanian Bogor.

Halim, C. N. \& Elok, Z. (2013). Studi Kemampuan Probiotik Isolat Bakteri Asam Laktat Penghasil Eksopolisakarida Tinggi Asal Sawi Asin (Brassica juncea). Jurnal Pangan dan Agroindustri, 1(1), 129-137.

Mirnejad, R., Ali, R.V., Jamal, R., Mohammad, E\& Vahhab,P.(2013). TheAntimicrobial Effect of Lactobacillus Casei Culture Supernatant Against Multiple Drug Resistant Clinical Isolates of Shigella Sonnei and Shigella Flexneri in Vitro. Iranian Red Crescent Medical Journal, 15(2), 122-126.

Nannen, N.L \& Hutkins, R.W. (1991). Intracelluler $\mathrm{pH}$ Effect in Lactic Acid Bacteria. Journal of Dairy Science, 74, 741-746.
Nurdini, A. L., Nuraida, L. \& Suwanto, A Suliantari. (2015). Mycrobial Growth Dynamics During Tempeh Fermentation in Two Different Home Industries. International Food Research Journal, 22(4), 1668-1674

Panjaitan, R., Nuraida, L \& Hariyadi, R. D. (2018). Seleksi Isolat Bakteri Asam Laktat Asal Tempe dan Tape sebagai Kandidat Probiotik. Jurnal Teknologi dan Industri Pangan, 29(2), 175-184.

Pato, U., Surono, I., Koesnandar, S. \& Hosono A. (2014). Hypocholesterolemic Effect of Indigenous Dadih Lactic Acid Bacteria by Deconjugation of Bile salts. Asian Australas. Journal Animal Science, 17(12), 1741-1745.

Pato, U., Vonny, S. D., Johan, F. K. \& Raja, D. H. H. (2017). Antibiotic Resistance and Antibacterial Activity Of Dadih Originated Lactobacillus Casei Subsp. Casei R-68 Against Food Borne Pathogens. Asian Journal of Microbiology, Biotechnology \& Environmental Sciences Paper, 19(3), 577-587.

Radlovic, N., Zoran, L., Biljana, V., Vladimir, R. \& Dusica, S. (2015). Acute Diarrhea in Children. Srpski Arhiv Za Celokupno Lekarstvo, 143(11-12), 755-762.

Rahmah, R.A., Bahar, M. \& Harjono, Y. (2017). Uji Daya Hambar Filtrat Metabolit Lactobacillus plantarum terhadap Pertumbuhan Shigella dysenteriae Secara in Vitro. Biogenesis, 5(1), 34-41.

Ratihwulan, H. (2016). Karakteristik Sensori Tape Ketan dan Tape Singkong dari Industri Rumah Tangga yang Berbeda di Bogor. Skripsi. Depatemen Ilmu dan Teknologi pangan, Institut Pertanian Bogor.

Ray, B. \& Daeschel, M. (1992). Food 


\section{JURNAL BIDDJATI}

http://journal.uinsgd.ac.id/index.php/biodjati

\begin{abstract}
Biopreservatives of Microbial Origin. Boca Raton: CRC Press.

Rusli, Amaliyah F \& Dwyana, Z. (2018). Potensi Bakteri Lactobacillus Acidophilus sebagai Atidiare dan Imonodulator. Jurnal Biologi Makasar, 3(2), 25-30.

Savadogo, A., Cheik, A. T., Ouattara., Imael, H.N., Bassole \& Alfred, S. T. (2004). Antimicrobial Activities of Lactic Acid Bacteria Strains Isolated from Burkina Faso Fermented Milk. Pakistan Journal of Nutrition, 3(3) 174-179.

Siegumfeldt, H., Rechninger, B.K \& Jacobsen, M. (2000). Dynamic Changes of Intraceluller $\mathrm{pH}$ in Individual Lactic Acid Bacterium Cells in Response to A Rapid Drop in Extracelluler $\mathrm{pH}$. Applied Environmental Microbiology, 66(6), 2330-2335.
\end{abstract}

Situmeng, A.M.F., Musthari \& Riadi. (2017). Isolasi dan uji aktivitas antimikroba BAL dari yaghurt dalam menghambat pertumbuhan bakteri E.coli dan S.typhi. Jurnal Biosain, 3(3), 144-152.

Sulmiyati, Nur, S.S ., Deka, U. F., Ratmawati, M. \& Fatma, M. (2011). The
Characteristics of Lactic Acid Bacteria Isolated from Indonesian Commercial Kefir Grain. Malaysian Journal of Microbiology, 14(17), 632-639.

Susanti, I., Retno, W. K., \& Fatim, I. (2007). Uji Sifat Probiotik Bakteri Asam Laktat Sebagai Kandidat Bahan Pangan Fungsional. Jurnal Teknologi dan Industri Pangan , 18(2), 89-95.

Tamime, A. Y ., Saarela, M., Sondergaard, A. K., Mistry, V. V. \& Shah, N. P. (2005). Production and Maintenance of Viability of Probiotic Micro-organisms in Dairy products. Oxford: Blackwell Publishing Ltd.

Touw, K.S. (2014). Identifikasi Bakteri Asam Laktat Dominan Selama Fermentasi Tempe dan Evaluasi Potensinya sebagai Probiotik. Skripsi. Depatemen Ilmu dan Teknologi pangan, Institut Pertanian Bogor.

Yulinery, T dan Nurhidayat, N (2013). Aktivitas Antimikroba dan Analisis Gen Plantarisin F dari Isolat Lactobacillus Asal Buah-buahan Tropis. Jurnal Ilmu Kefarmasian Indonesia, 11(2), 147-155. 